\title{
Effect of enhancers on the in vitro percutaneous absorption of piroxicam from compounding formulations
}

\author{
Francieli Furlan Bortolon', Mayumi Elisa Sato², Regina Celis da Silveira Andreazza1, \\ Tania Mari Bellé Bresolin ${ }^{*}$
}

${ }^{1}$ Núcleo de Pesquisas Químico-Farmacêuticas, Curso de Farmácia, Universidade do Vale do Itajaí, ${ }^{2}$ Departamento de Farmácia, Universidade Federal do Paraná

*Correspondence:

T. M. B. Bresolin

Curso de Farmácia

Universidade do Vale do Itajaí

Rua Uruguai, 458, bloco 27, sala 301

Caixa Postal 360

88 302-202 - Itajaí - SC, Brasil

E-mail: tbresolin@univali.br
Formulations of piroxicam in Lanette ${ }^{\circledR}(L)$ or Net Fs $(N)$ vehicles, with or without permeation enhancers, the ethanol (E) or propylene glycol $(P)$ were developed. The piroxicam permeation through porcine ear skin, in a Franz Cell was evaluated, comparing with a commercial product. The permeate was analyzed by high performance liquid chromatography (HPLC) using a $5 \mathrm{~mm} C_{18}$ column with mobile phase methanol:phosphate buffer (60:40), at $354 \mathrm{~nm}$ and the run time of $10 \mathrm{~min}$. This method was validated and the limit of quantification was $0.138 \mu \mathrm{g} / \mathrm{mL}$, with linearity over 0.02-5 $\mu \mathrm{g} / \mathrm{mL}$, without endogenous skin interference. The order of piroxicam permeation after $24 \mathrm{~h}$ was: $L E>L>$ Feldene ${ }^{\circledR}>N>$ $L P>N P>N E$. The L based formulations showed greater piroxicam permeation compared with $N$ based formulations, particularly up to $10 \mathrm{~h}$ of experiment. The ethanol enhancer provided the highest piroxicam permeation. The commercial product shows a different behavior, providing piroxicam permeation almost after $10 \mathrm{~h}$. These results show the development of effective, simple and economic percutaneous formulations of piroxicam allowing the choice of formulations for higher or lower piroxicam permeation.

\section{INTRODUCTION}

Piroxicam (4-hydroxy-2-methyl- $\mathrm{N}$-(2-pyridyl)- $2 \mathrm{H}$ 1,2-benzothiazine-3-carboxamide-1,1-di-oxide) is a non steroidal anti-inflammatory and analgesic agent. This drug has been widely used in the treatment of rheumatoid arthritis and other inflammatory disorders (Insel, 1991). It is well absorbed following oral administration however its use has been associated with a number of undesirable side effects on the stomach and kidneys in addition to gastric mucosal damage (Babar, Solanki, Cutie, 1990). These side effects may be overcome through topical administration of the drug (Schiantarelli et al., 1982). For this reason piroxicam is commercialized in topical products in a gel form.

The percutaneous absorption of drugs involves two 
consecutive processes: the release of the drug from the topical formulation, and its absorption into and through the skin, at the application site (Shima et al., 1981). One of the strategies used to decrease the barrier function of stratum corneum is enhancers.

Considerable research is currently being carried out, on chemical penetration enhancers, in order to improve drug penetration, and conventional substances may be used for this purpose (Barry, 1983; Martins, Veiga, 2002) as ethanol (Sloan et al., 1998; Zhao, Shing, Shing, 2001; Heard, Kung, Thomas, 2006) and propylene glycol (Santoyo et al., 1995; Gao, Singh, 1998; Bowen, Heard, 2006). Penetration enhancers that interact with lipids of the outermost layer of the skin allow better penetration of coadministered drugs (Cheong, Choi, 2003).

The principal purpose of this work is to develop an effective, simple, and economic percutaneous formulation of piroxicam, which can be produced in a compounding pharmacy, using conventional excipients and comparing the in vitro percutaneous absorption of these formulations with commercial available products. The suitability of the HPLC method for quantifying piroxicam in vitro percutaneous permeation study was demonstrated.

\section{MATERIAL AND METHODS}

\section{Reagents, materials and standard solution}

The materials used, in accordance with pharmaceutical purity grade, were: cetostearyl alcohol, sodium lauryl sulphate - Lanette ${ }^{\circledR}$ (Natural Farma), decyl oleate - Cetiol V, BHT, EDTA Na, ${ }_{2}$, ciclometicon - Silicon DC $245 \AA$ and Sorbitol (purchased from All Chemistry), silicone microemulsion - Net Fs ${ }^{\circledR}$ (Galena), piroxicam (DEG, $99.5 \%$ ), propylene glycol (Nuclear), Nipagim $\AA$, Nipazol $\AA$ and cetoestearyl alcohol (purchased from Purifarma), Natrosol ${ }^{\circledR}$ (Vital), mono glyceryl monoestearate (Croda), Triethanolamine and carbomer- Carbopol ETD 2020® (Dinaco). The solvents used for the analytical analyses were of chromatographic grade and were purchased from JTBaker (Phillipsburg, USA). All the others chemicals used were of reagent grade. The commercial product used was Feldene ${ }^{\circledR}$ $0.5 \%$ gel (Pfizer, Brazil).

A $500 \mu \mathrm{g} / \mathrm{mL}$ stock solution of piroxicam in $0.01 \mathrm{M}$ methanolic hydrochloric acid was diluted to $10 \mu \mathrm{g} / \mathrm{mL}$ as follows: $1 \mathrm{~mL}$ of stock solution was transferred to a volumetric flask of $50 \mathrm{~mL}$ and $25 \mathrm{~mL}$ of $0.01 \mathrm{M}$ methanolic hydrochloric acid were added, followed by $10 \mathrm{~mL}$ of ultrapure water, and the total volume was completed with $0.01 \mathrm{M}$ methanolic hydrochloric acid. Six standard solutions ( 0.02 to $5 \mu \mathrm{g} / \mathrm{mL}$ ) were prepared by further dilution of the $10 \mu \mathrm{g} / \mathrm{mL}$ stock solution, with appropriated volumes of $0.01 \mathrm{M}$ methanolic hydrochloric acid. The piroxicam solutions were freshly prepared, each day.

\section{Apparatus and chromatographic conditions}

The apparatus used for the HPLC analysis was a Shimadzu (Tokyo, Japan) chromatographic system equipped with Shimadzu LC 10AD-VP binary pump and Shimadzu SPD M10A $354 \mathrm{~nm}$ photo diode array detector. Samples were injected using a Rheodyne $7725 \mathrm{i}$, manual injector (Rohnert Park, C.A., USA), at $1.2 \mathrm{~mL} / \mathrm{min}$ flow, using a Phenomenex column (Luna RPC18, $5 \mathrm{~mm}, 4.6$ x $250 \mathrm{~mm}$ ), and a Shimadzu CTO-10A column over fit to $35^{\circ} \mathrm{C}$.

The mobile phase consisted of 60:40 methanol:buffer in an isocratic elution. The buffer consisted of $7.72 \mathrm{~g}$ anhydrous citric acid in $400 \mathrm{~mL}$ of water, and $5.35 \mathrm{~g}$ of dibasic sodium phosphate, separately dissolved in $100 \mathrm{~mL}$ of water. The phosphate solution was added to the citric acid solution, diluted with water to make $1000 \mathrm{~mL}$, and mixed. Solvents of HPLC were degassed by $\mathrm{N}_{2}$ gas, prior to use, and filtered through $0.45 \mathrm{~mm}$ regenerated cellulose membranes by vacuum. Data acquisition and integration were carried out using Shimadzu Class VP software (5.032 version).

\section{HPLC assay}

The piroxicam assay method in the permeated fluids was adapted to its raw material monography (United States Pharmacopeia, 2006), with the follow changes: the suggested wavelength of $254 \mathrm{~nm}$ was changed to $354 \mathrm{~nm}$, in view of the higher absorbance, and the organic phase of the mobile phase was increased, in order to decrease the analysis time. The analytical procedure was submitted to validation (Brasil, 2003), to demonstrate its suitability for analyzing the piroxicam in this transdermal permeation study.

The linearity was verified using concentrations of $0.02,0.05,0.5,1,2$ and $5 \mu \mathrm{g} / \mathrm{mL}$ of piroxicam, dissolved in $0.01 \mathrm{M}$ methanolic hydrochloric acid, in triplicate.

For the analysis of assay specificity, the retention times of the endogenous compounds in the matrix were compared with those of the piroxicam.

The precision of the method was tested within-day and between-day of the assay. Precision was expressed as the relative standard deviation (RSD) of replicate measurements. This study was developed with three concentrations $(0.05$, 0.5 and $2 \mu \mathrm{g} / \mathrm{mL}$ ) of piroxicam in $0.1 \mathrm{M}$ methanolic hydrochloric acid. Each concentration was assayed in triplicate, on the same day and on the other two different days, in triplicate. 
The accuracy of the assay method was defined as the recovery percentage, by the assay of known added amount of analyte $(2 \mu \mathrm{g} / \mathrm{mL})$ in a permeated sample (LE), in triplicate. The sample was previously divided into two aliquots, and the piroxicam present in the permeated sample was subtracted from the sample spiked with the analyte.

The limit of quantification (LOQ) was calculated by the follow equation:

$\mathrm{LOQ}=10 \mathrm{~S} / a$

where $\mathrm{S}$ is the standard deviation of linear coefficient of the calibration curve and $a$ is the angular coefficient of the calibration curve.

\section{Preparation of Piroxicam Formulations}

The piroxicam formulations are shown in Table I.

The components of formulations containing Lanette ${ }^{\circledR}$ were prepared by heating to $80^{\circ} \mathrm{C}$ i) the hydrophobic components over continuous stirring; and ii) the hydrophilic components with $50 \%$ of water, also over continuous stirring. Next, i) was added to ii) over stirring at $80{ }^{\circ} \mathrm{C}$, for $10 \mathrm{~min}$. To the resultant emulsion, a further $50 \%$ of water at room temperature was added, over continuous stirring. The silicon was added after emulsion at $40^{\circ} \mathrm{C}$. The Lanette ${ }^{\circledR}$ based formulation was designated LP and LE, due to the corresponding propylene glycol and ethanol enhancers, respectively. No enhancer was added to the L formulation.
The formulations containing Net FS ${ }^{\circledR}$ were prepared by mixing all the hydrophobic and hydrophilic components at room temperature, over continuous stirring. Triethanolamine was added to allow a pH of 7.0, and then, the Net FS ${ }^{\circledR}$ was added slowly, followed by continuous stirring, to achieve the desired viscosity and homogeneity. The NetFS $₫$ formulations were also designated NP, NE and N as described above.

These formulations (Table I) were selected after a trial using various formulations, submitted to stress tests with freezing-defrosting cycles (data not show), followed by centrifugation with analysis of the organoleptic characters, appearance, $\mathrm{pH}$ and viscosity. The six formulation selected (LP, LE, L, NP, NE and N), shown in Table I, were finally submitted and approved in a stability study at 25 and $40{ }^{\circ} \mathrm{C}$ for 4 months (data not shown).

\section{Skin Preparation}

Porcine ears obtained from a local slaughterhouse, were cleaned under cold running water and the outer region of the ear was cut. The whole skin was cut, and using a surgical blade, the skin from the outer surface of a freshly excised ear was carefully dissected to remove the fat and blood vessels, and immediately frozen for use within one month. Slice thickness ranged from 2.0 to $2.5 \mathrm{~mm}$.

\section{In vitro piroxicam permeation}

The diffusion cell used was similar to the Franz diffusion assembly. The excised porcine ear membrane was

TABLE I - Compounding percutaneous formulations of piroxicam

\begin{tabular}{|c|c|c|c|c|c|c|}
\hline \multirow[t]{2}{*}{ Components } & \multicolumn{6}{|c|}{$\%$} \\
\hline & LP & LE & $\mathrm{L}$ & NP & NE & $\mathrm{N}$ \\
\hline Piroxicam & 0.5 & 0.5 & 0.5 & 0.5 & 0.5 & 0.5 \\
\hline Lanette $\mathrm{N} \circledast$ & 5 & 5 & 5 & - & - & - \\
\hline 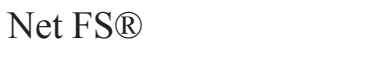 & - & - & - & 1 & 1 & 1 \\
\hline Propylene glycol & 10 & - & - & 10 & - & - \\
\hline Ethanol & - & 10 & - & - & 10 & - \\
\hline Glyceryl Monoestearate & 5 & 5 & 5 & - & - & - \\
\hline Cetiol V® & 2.5 & 2.5 & 2.5 & - & - & - \\
\hline Cetoestearyl alcohol & 5 & 5 & 5 & - & - & - \\
\hline Natrosol ${ }^{\circledR}$ & 1 & 1 & 1 & - & - & - \\
\hline Ciclometicon DC $245 \AA$ & 3 & 3 & 3 & 3 & 3 & 3 \\
\hline Carbopol ETD 2020® & - & - & - & 1 & 1 & 1 \\
\hline Triethanolamine & - & - & - & qsp & qsp & qsp \\
\hline Purified Water & 67.6 & 67.6 & 77.6 & 84.1 & 84.1 & 94.1 \\
\hline Appearance* & $\mathrm{O} / \mathrm{H}$ & $\mathrm{O} / \mathrm{H}$ & $\mathrm{O} / \mathrm{H}$ & $\mathrm{T} / \mathrm{H}$ & $\mathrm{T} / \mathrm{H}$ & $\mathrm{T} / \mathrm{H}$ \\
\hline
\end{tabular}

*O = opaque; $\mathrm{H}=$ homogeneous; $\mathrm{T}=$ transparent. 
set in place with the stratum corneum facing the donor compartment and the dermis side facing the receptor. Two milliliters of percutaneous formulation was measured with a syringe and transferred to the skin surface in the donor compartment, which was sealed from the atmosphere with a plastic film (parafilm ${ }^{\circledR}$ ). The receptor compartment of the cell was filled with $10 \mathrm{~mL}$ of phosphate buffer ( $\mathrm{pH}$ 7.4).

During the experiments, the solution in the receptor compartment was kept at $37 \pm 0.5^{\circ} \mathrm{C}$ by thermostatically controlled water, and stirred with teflon-coated magnetic stirring bars. Each experiment was carried out in triplicate.

Samples $(1 \mathrm{~mL})$ were removed from the receptor compartment at regular intervals, and an equal volume of fresh phosphate buffer ( $\mathrm{pH}$ 7.4) was added. The samples were assayed using HPLC.

The diffusional area of cell (ranged from $1.73-1.78 \mathrm{~cm}^{2}$ ) was taken into account for the calculation of piroxicam permeation.

Piroxicam steady state flux $(\mathrm{J})$ was estimated from the slope of the straight line portion of the cumulative amount of drug per area (A) against time profiles (Florence, Attwood, 2003). Different kinetics modes, as Higuchi (Higuchi, 1961), first order and zero order were applied to observe the better fit of curves.

\section{RESULTS AND DISCUSSION}

In this paper we describe the in vitro permeation study of percutaneous piroxicam formulations accessible to compounding pharmacy, with two different enhancers, comparing these with a commercial product. In addition, a practical, rapid and suitable assay method is suggested for analyzing the piroxicam permeated through the porcine ear skin.
It is emphasized that the method for quantification of drugs from the samples obtained in permeation in vitro studies must be specific, since the samples are frequently contaminated with endogenous skin compounds. In addition, these methods must also be sensitive, due to the low concentration of the piroxicam in the aliquots of the skin permeation studies (Doliwa et al., 2001a). These authors reported a method by RP HPLC for determining piroxicam in the transdermal permeation study. However, a special $\mathrm{pH}$-stable column (Scharlau $\mathrm{C}_{18}$ of $12 \times 0.26 \mathrm{~cm}$ ) was used, allowing a $\mathrm{pH}$ of 2.8 of the mobile phase, in which the piroxicam is fully unionized $\left(\mathrm{pKa}_{1}=1.86\right)$.

In the piroxicam assay method developed in the present work, with a conventional RP column, the substance has a retention time of $6.2 \mathrm{~min}$ (Figure 1). As shows Figure 1, the skin compounds and the formulations did not interfere with the analysis of piroxicam. There was clear resolution of the compound of interest $(R=20)$ without any endogenous source of interference.

The assay shows linearity between the area $(y)$ and the corresponding piroxicam concentration $(x)$ over 0.02 $5 \mu \mathrm{g} / \mathrm{mL}$ range (typical equation, $y=53828 x+122.9$ ). The result by least-squares linear regression analysis of curves $(n=3)$ was $>0.999$. The RSD of each point of calibration standard was $<10 \%$. Doliwa et al. (2001a) reported linearity to piroxicam HPLC assay in the range of 0.05 $9 \mu \mathrm{g} / \mathrm{mL}$, with $\mathrm{R}>0.994$.

The calculated LOQ of piroxicam was $0.138 \mu \mathrm{g} / \mathrm{mL}$ and the results for within-day and between-day precision are show in Table II. The RSD values were $<10 \%$ in both cases, and lower at the higher concentrations. The RSD of the lower concentration is $>3 \%$, probably due to this value is $<$ LOQ of $0.138 \mu \mathrm{g} / \mathrm{mL}$. These results are similar to those found by Doliwa et al. (2001a).

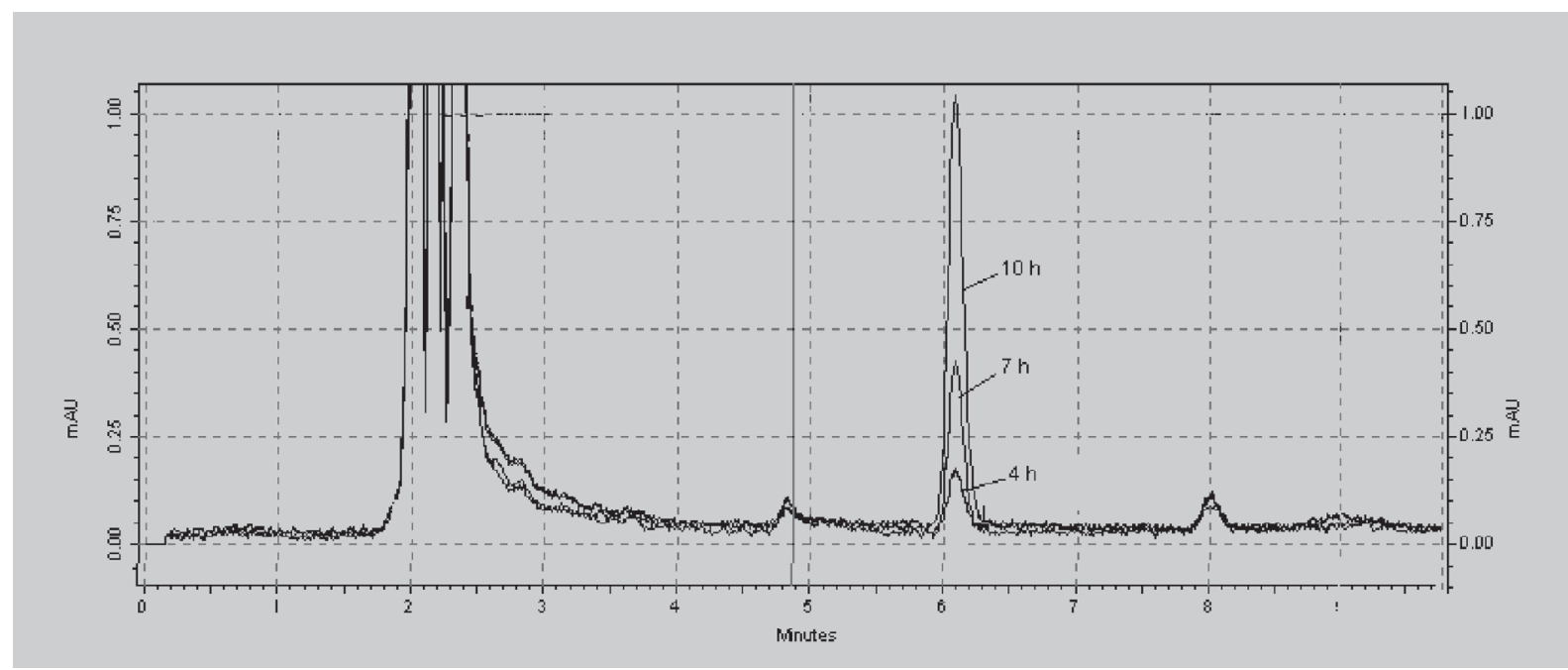

FIGURE 1 - Permeated sample of LE formulations after 4, 7 and $10 \mathrm{~h}$. 
TABLE II - Analysis of within-day and between-day precision of the HPLC method for assay piroxicam

\begin{tabular}{lcc}
\hline $\begin{array}{l}\text { Theoretical } \\
\text { concentration } \\
(\mu \mathrm{g} / \mathrm{mL})\end{array}$ & $\begin{array}{c}\text { within-day } \\
\text { variability } \\
(n=6) \text { RSD }(\%)\end{array}$ & $\begin{array}{c}\text { between-day } \\
\text { variability } \\
(n=9) \operatorname{RSD}(\%)\end{array}$ \\
\hline 0.05 & 7.3 & 7.8 \\
0.5 & 2.8 & 2.4 \\
2 & 1.8 & 1.7 \\
\hline
\end{tabular}

The accuracy of the method after standard addition in a permeated sample is showed Table III and is within acceptable limit.

TABLE III - Analysis of accuracy of the HPLC method for piroxicam assay after transdermal permeation experiments

\begin{tabular}{lcc}
\hline $\begin{array}{l}\text { Concentration } \\
\text { added }(\mu \mathrm{g} / \mathrm{mL})\end{array}$ & $\begin{array}{c}\text { Concentration founded } \\
(\text { mean } \pm \text { S.D. }) \\
(\mu \mathrm{g} / \mathrm{mL})\end{array}$ & $\begin{array}{c}\text { Accuracy } \\
(\%)\end{array}$ \\
\hline no added & $0.096 \pm 0.009$ & - \\
2 & $2.049 \pm 0.051$ & 2.4 \\
\hline
\end{tabular}

The method for piroxicam assay in the percutaneous permeation study proved to be suitable, even with a conventional HPLC RP column. The results for piroxicam permeation from the different formulations are shown in Figure 2.

The piroxicam $\left(\mathrm{pK}_{2}\right.$ 5.1) (Drug Information, 1988) is a slightly lipophilic drug (Doliwa et al., 2001b), with log P of 1.2466 (Pénzes et al., 2005) commonly vehiculed in hydrophilic matrices, as a gel-type. A good potency of penetration is most probable when $\log \mathrm{P}$ is close to 2 (Beetge et al., 2000) so, the addition of enhancers, ethanol and propylene glycol, is interesting in view of increase the drug permeation. Other drugs with a similar balanced lipophilic/hydrophilic character, as ketoprofen, showed a flux remarkably enhanced when $2 \%$ of alcohol terpen (menthol) was applied (Nakamura et al., 1996) and this effect was attributed to the change of dense barrier of stratum corneum of the skin by the menthol.

In this work, all the formulations showed a similar piroxicam permeation profile, through the porcine ear skin, however, the LE formulation presented faster and higher permeation, compared with other products (Figure 2). The order of piroxicam permeation was: $\mathrm{LE}>\mathrm{L}>$ Feldene ${ }^{\mathrm{C}}>\mathrm{N}>\mathrm{LP}>$ $\mathrm{NP}>\mathrm{NE}$. Comparing the emulgent agents used, the Lanette $\mathrm{N} 囚$ showed higher drug permeation than Net FS ${ }^{\circledR}$. This could be explained by the barrier role of Net FS ${ }^{\circledR}$, a silicon microemulsion (Zhai, Maibach, 2003) which may decrease piroxicam transport. On the other hand, the vehicle Lanette is an anionic matrix of a lipophilic nature, which enhances piroxicam permeation. The higher drug permeation by the use of anionic tensoactive may be attributed to the increase of lipid fluidization in the stratum corneum, due to the fatty alcohols in its composition (Kitagawa, End, Kameteni, 1985), and also, to the effect over queratin helix, allowing reversible denaturation that forms cavities and loss of water absorption ability (Santos, Bahia, 1995; Bronaugh, Franz, 1986; Nokhodchi et al., 2003).

In addition, even without enhancer $(\mathrm{L})$, Lanette $\mathrm{N} \otimes$ allowed similar piroxicam permeation to the commercial product. The latter is a carbomer gel, in which the piroxicam is solubilized in benzilic alcohol and ethanol, which may be responsible for enhancing the piroxicam permeation in this product (Barry, Williams, 2004).

In the formulations, the ethanol showed a major enhancing effect. Ethanol is a potent solvent for both polar and non-polar species, and it is feasible that a small amount of ethanol is capable of leaching significant quantities of non-covalent bound amphiphilic stratum corneum lipids (Bommannan, Potts, Guy, 1991), which would have the effect modulating the skin barrier. On the other hand, the different solubilities of piroxicam in ethanol and propylene glycol may play a role, affecting permeation of the drug. Also, the higher viscosities of $\mathrm{N}$ based formulations $(3,966$ and $2,805 \mathrm{mPa}$.s for $\mathrm{NP}$ and $\mathrm{NE}$, respectively) in comparison with $\mathrm{L}$ based formulations $(3,175$ and 2,405 $\mathrm{mPa}$.s for LP and LE, respectively), may affect the drug diffusion from product to the exterior, to be able to penetration in the skin. The $\mathrm{N}$ based formulations showed higher viscosity, probably due to the Net Fs ${ }^{\circledR}$ contribution (Garcia, Rubio, Aliaga, 1998), and the enhancer ethanol, that provided the higher permeation of piroxicam, showed an effect of decrease both formulations viscosity values.

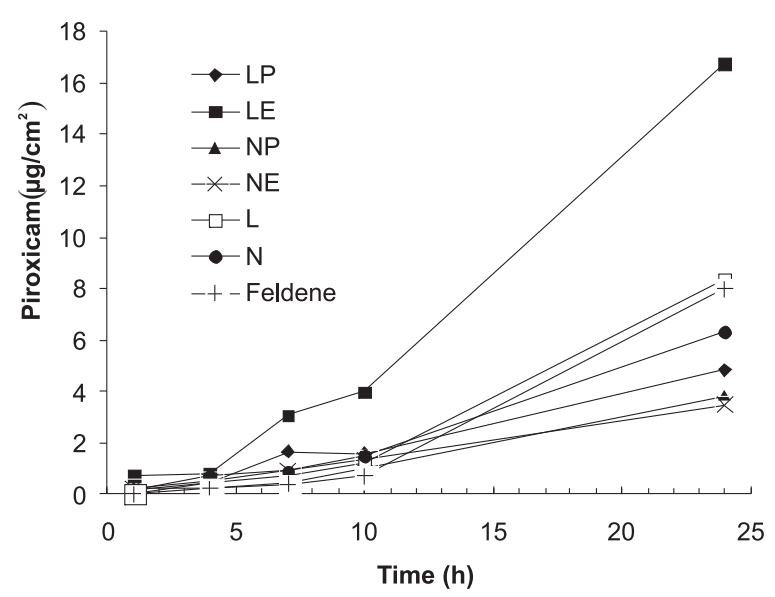

FIGURE 2 - In vitro permeation of piroxicam of different formulations. 
Table IV - Kinetics parameters of in vitro piroxicam permeation from formulations, at steady-state

\begin{tabular}{lcccccc}
\hline Formulation & \multicolumn{2}{c}{ Zero order } & \multicolumn{2}{c}{ First order } & \multicolumn{2}{c}{ Higuchi } \\
& $\mathrm{J}\left(\mu \mathrm{g} / \mathrm{cm}^{2} / \mathrm{h}\right)$ & $\mathrm{R}^{2}$ & $\mathrm{~J}\left(\mu \mathrm{g} / \mathrm{cm}^{2} / \mathrm{h}\right)$ & $\mathrm{R}^{2}$ & $\mathrm{~J}\left(\mu \mathrm{g} / \mathrm{cm}^{2} / \mathrm{h}\right)$ & $\mathrm{R}^{2}$ \\
\hline $\mathrm{LP}$ & 0.21 & 0.9730 & 5.53 & 0.9158 & 1.49 & 0.9599 \\
$\mathrm{LE}$ & 0.81 & 0.9882 & 20.74 & 0.8887 & 5.65 & 0.9562 \\
$\mathrm{NP}$ & 0.19 & 0.9885 & 4.78 & 0.8787 & 1.31 & 0.9524 \\
$\mathrm{NE}$ & 0.15 & 0.9999 & 3.92 & 0.9333 & 10.06 & 0.9844 \\
$\mathrm{~L}$ & 0.42 & 0.9596 & 10.49 & 0.8105 & 2.91 & 0.9036 \\
$\mathrm{~N}$ & 0.29 & 0.9751 & 7.44 & 0.8425 & 2.05 & 0.9276 \\
Feldene ${ }^{\mathbb{B}}$ & 0.41 & 0.9454 & 10.23 & 0.7855 & 2.85 & 0.8840 \\
\hline
\end{tabular}

$\mathrm{J}=$ flux $; \mathrm{R}^{2}=$ correlation coefficient

The Table IV shows the kinetics parameters of in vitro percutaneous permeation of piroxicam from the different formulations, using the model of zero order, first order and Higuchi.

For all the formulations, the piroxicam in vitro permeation showed better fit with zero order kinetics (Table IV), characteristic of formulations of infinite doses (Wester, Maibch, 1989). The order of piroxicam flux values at steady state from the formulations was the same observed in Figure 2, LE $>$ L $>$ Feldene ${ }^{\circledR}>N>L P>N P>N E$. The enhancing ratio of ethanol in the Lanette formulations was 1.9, however, no enhancing effect was observed for the Net Fs ${ }^{\circledR}$ formulations, for both components, ethanol and propylene glycol.

\section{CONCLUSIONS}

Lanette ${ }^{\circledR}$ based formulations showed greater piroxicam permeation through the porcine ear membrane, compared with Net FS ${ }^{\circledR}$ based formulations, particularly up to $10 \mathrm{~h}$ of experiment. In the Net FS $®$ based formulations, the ethanol and propylene glycol decreased the piroxicam permeation close to $24 \mathrm{~h}$, in relation to the absence of these enhancers, without significant increase in the drug permeation after $10 \mathrm{~h}$. The commercial product presented a different piroxicam permeation behavior, which showed an increase after $10 \mathrm{~h}$. The two enhancers used showed different effects, depending on the vehicle used in the piroxicam permeation, and the final rate of piroxicam permeation was dependant on the contribution of the various components of the final formulation, providing compounding formulations with higher or lower piroxicam permeation in comparison to the commercial product.

\section{RESUMO}

\section{Efeito de promotores na absorção percutânea in vitro do piroxicam a partir de formulações magistrais}

Formulações de piroxicam com base Lanette ${ }^{\circledR}(L)$ ou Net Fs ${ }^{\circledR}(N)$ ), com ou sem promotores de absorção (etanol-E ou propilenoglicol-P), foram desenvolvidas. O estudo de permeação de piroxicam das formulações foi realizado em célula de Franz, usando pele de porco e o desempenho foi comparado com a especialidade farmacêutica. O fármaco permeado foi analisado por método desenvolvido por CLAE usando uma coluna analítica $C_{18}$ de $15 \times 0,46 \mathrm{~cm}$, com fase móvel metanol: tampão fosfato (60:40), comprimento de onda de $354 \mathrm{~nm}$ e o tempo de corrida foi de $10 \mathrm{~min}$. O ensaio foi validado e apresentou limite de quantificação de $0,138 \mu \mathrm{g} / \mathrm{mL}$, linearidade na faixa de 0,02-5 $\mu \mathrm{g} / \mathrm{mL}$ e não ocorreu interferência de substâncias endógenas da pele ou da formulação. A ordem de permeação de piroxicam, após 24 horas, foi $L E>L>$ Feldene ${ }^{\circledR}>N>L P>N P>N E$. As formulações com $L$ mostraram maior permeação de piroxicam quando comparado com as formulações de base N. Entre os promotores, o etanol promoveu a maior permeação do fármaco. Os resultados mostraram o desenvolvimento de formulações tópicas econômicas, de fácil obtenção, com efetiva permeação de piroxicam possibilitando a escolha de formulações com maior ou menor permeação do fármaco.

UNITERMOS: Piroxicam/permeação. Permeação cutânea. Promotor químico. Etanol. Propilenoglicol. Validação analítica. 


\section{ACKNOWLEDGEMENTS}

The authors wish to thank Laboratório de Produção e Análise de Medicamentos (UNIVALI-LAPAM) for providing their facilities, the Pharmacy Department of Universidade Federal do Paraná (UFPR), the Fundação de Amparo à Pesquisa do Estado de Santa Catarina (FAPESC) and PIBIC-CNPq.

\section{REFERENCES}

BRASIL Resolução REn. 899 de 29 de maio de 2003. Diário Oficial da União, 02 jun 2003. p.5.

BABAR, A.; SOLANKI, U.D.; CUTIE, A.J. Piroxicam release from dermatological bases in vitro studies using cellulose membrane and hairless mouse skin. Drug Dev. Ind. Pharm., v.16, n.3, p.523-540, 1990.

CHEONG, H.A.; CHOI, H.K. Effect of ethanolamine salts and enhancers on the percutaneous absorption of piroxicam from a pressure sensitive adhesive matrix. Eur. J. Pharm. Sci., v.18, p.149-153, 2003.

BARRY, B.W. Dermatological formulation: percutaneous absorption. New York: Marcel Dekker, 1983. p.1-233.

BARRY, B, W.; WILLIAMS, A., C. Penetration enhancers. Adv. Drug Deliv. Rev., v.56, p.603-618, 2004.

BEETGE, E.; DU PLESSIS, J.; MÜLLER, D.G.; GOOSE, C.; VAN RENSBURG, F.J. The influence of the physiochemical characteristcs and pharmacokinetics properties of selected NSAID's on their transdermal absorption. Int. J. Pharm., v.193, p.261-264, 2000.

BOMMANNAN, D.; POTTS, R.O.; GUY, R.H. Examination of the effect of ethanol on human stratum corneum in vivo using infrared spectroscopy. J. Control. Rel., v.16, p.299-304, 1991.

BOWEN, J.L.; HEARD, C.M. Film drying and complexation effects in the simultaneous skin permeation of ketoprofen and propylene glycol from simple gel formulations. Int. $J$. Pharm., v.307, p.251-257, 2006.

BRONAUGH,R. L.; FRANZ, T. J. Vehicle effects on percutaneous absorption in vivo and in vitro comparisons with human skin. Br. J. Dermatol., v.115, p.1-11. 1986.
DOLIWA, A.; SANTOYO, S.; CAMPANERO, M. A.; YGARTUA, P. Sensitive LC determination of piroxicam after in vitro transdermal permeation studies. J. Pharm. Biomed. Anal., v.26, p.531-537, 2001a.

DOLIWA, A.; SANTOYO, S.; YGARTUA, P. Effect of passive and iontophoretic skin pretreatments with terpenes on the in vitro skin transport of piroxicam. Int. J. Pharm., v.229, p.37-44, $2001 b$.

DRUG Information. American Society of Hospital Pharmacists. Bethesda: American Society of HealthSystem Pharmacists, 1988. 1038p.

FLORENCE, A.T.; ATTWOOD, D. Princípios físicoquímicos em farmácia. São Paulo: Edusp, 2003. 732p.

GARCIA, M. T. C.; RUBIO, L. R.; ALIAGA, J. L. V. Monografias farmacéuticas. Província de Alicante: Olmedilla, 1998. 1088p.

GAO, S.; SINGH, J. Effect of oleic acid/ethanol and oleic acid/ propylene glycol on the in vitro percutaneous absorption of 5-fluorouracil and tamoxifen and the macroscopic barrier property of porcine epidermis. Int. J. Pharm., v.165, p.45-55, 1998.

HEARD, C.M.; KUNG, D.; THOMAS, C.P. Skin penetration enhancement of mephenamic acid by ethanol and 1,8cineole can be explained by the "pull" effect. Int. J. Pharm., v.321, p.167-170, 2006.

HIGUCHI, T. Rate of release of medicaments from ointment bases containing drugs in suspension. J. Pharm. Sci., v.50, p.874-875, 1961.

INSEL, P.A. Autacoids: Drug Therapy of Inflammation. In: GILMAN, T.W.; RALL, A.S.; TAYLOR, N.P. (Eds.). Goodman and Gilman's The Pharmacological Basis of Therapeutics. 8. ed. New York: McGraw-Hill, 1991. p.668-669.

KITAGAWA, S.; END, J.; KAMETANI, F. Effects of longchain cis-unsaturated fatty acids and their alcohol analogs on aggregation on bovine platelets and their relation with membrane fluidity change. Biochim. Biophys. Acta, v.818, p.391-397, 1985.

MARTINS, M. R. F. M.; VEIGA, F. Promotores de permeaçäo para a liberaçäo transdérmica de fármacos: uma nova aplicaçäo para as ciclodextrinas. Rev. Bras. Ciênc. Farm., v.38, p.33-54, 2002. 
NOKHODCHI, A.; SHOKRI, J.; DASHBOLAGHI, A. et al. The enhancement effect of surfactants on the penetration of lorazepam through rat skin. Int. J. Pharm., v.50, p.359$369,2003$.

NAKAMURA, Y.; TAKAYAMA, K.; HIGASHYAMA, K.; SUZUKI, T.; NAGAI, T. Promoting Effect of $O$ ethylmenthol on the percutaneous absorption of ketoprofen. Int. J. Pharm., v.145, p.29-36, 1996.

PÉNZES, T.; BLAZSÓ, G.; AIHNER, Z.; FALKAY, G.; ERÕS, I. Topical absorption of piroxicam from organogels -in vitro and in vivo correlations. Int. J. Pharm., v.298, p.47-54, 2005.

SANTOS, D.; BAHIA, M. F. G. Promotores de absorção percutânea. Cosmet. Toilet., v.7, p.15-17, 1995.

SANTOYO, S.; ARELLANO, A.; YGARTUA, P.; MARTÍN, C. Penetration enhancer effects on the in vitro percutaneous absorption of piroxicam though rat skin. Int. J. Pharm., v.117, p.219-224, 1995.
SCHIANTARELLI, P.; CADEL, S.; ARCEBI, D.; PAVESI, L. Antiinflammatory activity and bioavailability of percutaneous piroxicam. Arzneim.-Forsch. Drug, v.32, p.230-235, 1982.

SHIMA, K.; MATSUKA, C.; HIROSE, M.; NOGUCHI, T.; YAMASHIRA,Y. Bipharmaceutical characteristics of indometacine gel ointment. Chem. Pharm. Bul.,v.29, suppl.1, p. 2338-2343, 1981.

SLOAN, K.B.; BEALL, H.D.; TAYLOR, H.E.; GETZ, J.J.; VILLANEUVA, R.; NIPPER, R.; SMITH, K. Transdermal delivery of theophylline from alcohol vehicles. Int. J. Pharm., v.171, p.185-193, 1998.

UNITED STATES PHARMACOPEIA. 29. ed. Rockville: The United States Pharmacopeial Convention, 2006. p. 892-892.

ZHAI, H., MAIBACH, H.I. Effects of occlusion : percutaneous absorption. Cosmet. Toilet., v.118, p.16-19, 2003.

ZHAO, K.; SINGH, S.; SINGH, J. Effect of menthone on the in vitro percutaneous absorption of tamoxifen and skin reversibility. Int. J. Pharm., v.219, p.177-181, 2001.

Recebido para publicação em 18 de junho de 2007 Aceito para publicação em 11 de abril de 2008 